\title{
Effect of Pullulan and Hydrocolloids on Rheological Properties and Quality Parameters of Wheat-Soy Baladi Bread
}

\author{
Sati Y. Al-Dalain ${ }^{1}$, Mohamed K. Morsy ${ }^{2 *}$ \\ ${ }^{1}$ Department of Medical Support, Al-Karak University College, Al-Balqa Applied University, Salt, Jordan \\ ${ }^{2}$ Department of Food Technology, Faculty of Agriculture, Benha University, Qaluobia, Egypt \\ Email: *mohamed.abdelhafez@fagr.bu.edu.eg
}

How to cite this paper: Al-Dalain, S.Y. and Morsy, M.K. (2018) Effect of Pullulan and Hydrocolloids on Rheological Properties and Quality Parameters of Wheat-Soy Baladi Bread. Food and Nutrition Sciences, 9, 32-45.

https://doi.org/10.4236/fns.2018.91003

Received: December 11, 2017

Accepted: January 28, 2018

Published: January 31, 2018

Copyright $\odot 2018$ by authors and Scientific Research Publishing Inc. This work is licensed under the Creative Commons Attribution International License (CC BY 4.0).

http://creativecommons.org/licenses/by/4.0/

\begin{abstract}
Baladi bread is a staple food in Egypt and high nutritive value however, stales rapidly. The aim of the study was to conduct a comparative evaluation of pullulan and hydrocolloid combinations on rheological properties and quality parameters of wheat-soy baladi bread. Pullulan polysaccharides $(\mathrm{Pu})$ and hydrocolloids as Arabic gum (AG), K-carrageenan (KC), pectin (P), and xanthan gum (XG) were applied. Rheological properties of samples included $\mathrm{Pu}$ and hydrocolloids were analyzed through extensiograph and farinograph. The crust color, staling, and sensory attributes of bread were evaluated. Results revealed that wheat flour (WF) has lower water absorption capacity, dough development time, mixing tolerance index, and resistance to extension however, has higher dough stability, extensibility, and dough energy compared to wheat-soy flour (WSF). Pu and/or hydrocolloids addition to WSF dough evidently improved bread quality. Pu was significantly enhanced crust color and yielded fresher bread relative to control. Additionally, $\mathrm{Pu}$ showed the highest Alkaline Water Retention Capacity (AWRC) value after 5 days at $25^{\circ} \mathrm{C} \pm 2^{\circ} \mathrm{C}$. Results demonstrated that hydrocolloids especially pullulan can significantly improve dough properties, baking quality, sensory acceptability, and delay staling of wheat-soy baladi bread.
\end{abstract}

\section{Keywords}

Baladi Bread, Hydrocolloids, Pullulan, Rheological Properties, Soy Flour

\section{Introduction}

Baladi bread is a staple food in Egypt and represents a reliable source of carbohydrates, dietary fibers, minerals, and vitamins. In Egypt, there is a major gap 
between wheat production and consumption of around 45\% [1]. The best way to overcome this problem is to identify local grain sources that could be utilized in combination with wheat flour to produce bread. Recently, the Egyptian government attempted to solve this problem by replacing wheat flour with corn flour by up to $20 \%$. However, the resulting bread exhibits various technical problems, including rapid staling and deterioration [2].

Soybean flour (Glycine max L.) is a major food ingredient that is relatively inexpensive and has high nutritional value. Soybean flour contains nearly $45 \%$ protein, including bioactive proteins such as $\alpha$-amylase and lipoxygenase, which are important for the bread making procedure [3]. The addition of up to $10 \%$ soy flour does not affect the bread making process [4] and was found to increase the protein, micro-, and macro-nutrient contents, improve dough resistance, intensify the crust color, and center color of bread. However, the staling problem in baladi bread still found.

Recent studies have reported that incorporation of hydrocolloids improves moisture retention and control water mobility, regulates rheological properties, and prevents the staling of bread [5]. Meanwhile, the effects of hydrocolloids on dough and bread properties depend on several factors, including particle size, molecular structure, and type of the hydrocolloids [6]. The hydroxyl groups in the hydrocolloid structure facilitate interactions with water through hydrogen bonding in the wheat dough [7].

The uses of hydrocolloids, such as Arabic gum (AG), K-carrageenan (KC), pectin $(\mathrm{P})$, and xanthan gum $(\mathrm{XG})$, were previously evaluated in cake making. A previous study [8] demonstrated that addition of XG and AG conditionally increased the batter density and consistency of cake samples. Moreover, the inclusion of XG, AG, or hydroxypropyl methylcellulose (HPMC) improved the panelists overall sensory score of yellow layered cakes [9].

One study demonstrated that HPMC improved the bread volume and reduced crumb hardening of bread [10]. Meanwhile, the addition of XG or sodium alginate (SA) was found to soften the white bread by inhibiting gluten-starch interactions [11]. Other studies [12] demonstrated that high methoxyl pectin (HMP) content reinforced the rheological properties of the dough and improved the specific loaf volume through the formation of hydrophilic complexes between the anionic groups of pectin and gluten. Moreover, the addition of

K-carrageenan was shown to improve the stability of wheat dough during proofing [13].

Pullulan $(\mathrm{Pu})$ is an extracellular polysaccharide produced by the fungus $A u$ reobasidium pullulans. Pu comprises linearly polymerized $\alpha$-trisaccharide units [14]. The degree of Pu polymerization ranges from 100 to $5000 \alpha$-glucopyranoside units. The molecular weight of the polymer varies between $10^{3}$ and $10^{6}$ a.m.u. Pu was approved as generally recognized as safe (GRAS) by the Food and Drug Administration [15] and exhibits highly desirable properties because it is tasteless, odorless, and has high solubility in water. Pu has been recently utilized as 
edible film and coating for meat products and eggs [16] [17]. Unfortunately, the functional properties of $\mathrm{Pu}$ in bread making are limited.

A few studies from literature have reported the use of hydrocolloids as anti-staling agents in bread however, no evidence in the literature about the effects of $\mathrm{Pu}$ on bread quality. Hence, the present study aimed to investigate the influence of $\mathrm{Pu}$ compared to AG, KC, P, and XG hydrocolloids on the rheological properties and quality parameters of wheat-soy baladi bread.

\section{Materials and Methods}

\subsection{Raw Materials and Additives}

Commercial wheat flour (WF; $82 \%$ extraction) was purchased from the North Cairo Flour Mills Company, Egypt in May 2016. Defatted soy flour (DSF; 60 mesh sieved) was obtained from the Agricultural Research Center (ARC), Giza, Egypt. Arabic gum (AG; E-414), K-carrageenan (K-C; E-407), pectin (P; E-440), and xanthan gum (XG; E-415) were purchased from Sigma-Aldrich (St. Louis, USA). Pullulan (Pu; E1204) was obtained from the Hayashibara Company (Okayama, Japan). Other ingredients, including fine salt (S; Bono, Egyptian Salts \& Minerals Co., Egypt) and instant dry active yeast (Saccharomyces cerevisiae), were obtained from a local supermarket in Cairo, Egypt. All additives are generally recognized as safe (GRAS). The structure of hydrocolloids is shown in Figure 1.

\subsection{Preparation of Flour Blends}

The $\mathrm{Pu}$ and four types of hydrocolloids were used in varying concentrations for the preparation of flour blends as $\mathrm{Pu}(0.1 \%, 0.2 \%$, and $0.4 \%, \mathrm{w} / \mathrm{w}), \mathrm{AG}(0.5 \%$ and $1 \%, \mathrm{w} / \mathrm{w}), \mathrm{KC}(0.2 \%$ and $0.4 \%, \mathrm{w} / \mathrm{w})$, pectin $(0.5 \%$ and $1 \%, \mathrm{w} / \mathrm{w})$, and XG $(0.5 \%$ and $1 \%, \mathrm{w} / \mathrm{w})$ based on dry weight of flour. The five examined materials were added (individually and/or combination) to wheat-soy flour (WF: DSF; 90:10) in seven baking trails according to Table 1 . All samples were blended thoroughly and stored in airtight containers at $5^{\circ} \mathrm{C}-7^{\circ} \mathrm{C}$ until use.

Table 1. Hydrocolloids types and concentrations used in wheat-soy baladi bread production.

\begin{tabular}{cccccc}
\hline \multirow{2}{*}{ Treatments $^{\mathbf{a}}$} & \multicolumn{5}{c}{ Hydrocolloids types } \\
\cline { 2 - 6 } & AG & KC & P & XG & Pu \\
\hline T1 & 0.5 & 0.2 & - & - & - \\
T2 & 1 & 0.4 & - & - & - \\
T3 & - & - & 1 & 0.5 & - \\
T4 & - & - & 0.5 & 1 & - \\
T5 & - & - & - & - & 0.1 \\
T6 & - & - & - & - & 0.2 \\
T7 & - & - & - & - & 0.4 \\
\hline
\end{tabular}

${ }^{\mathrm{a}}$ Weight of hydrocolloids based on (g/100g flour). AG: Arabic gum, KC: K-carrageenan, P: pectin, XG: xanthan gum, and Pu: pullulan. 


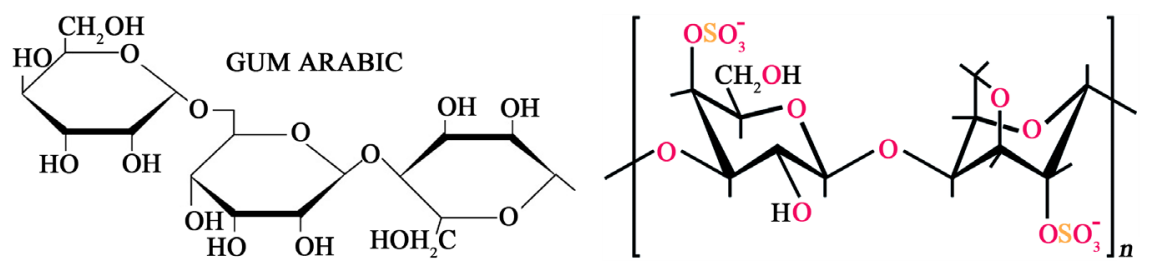

Arabic Gum (AG; E-414)

K-Carrageenan (K-C; E-407)

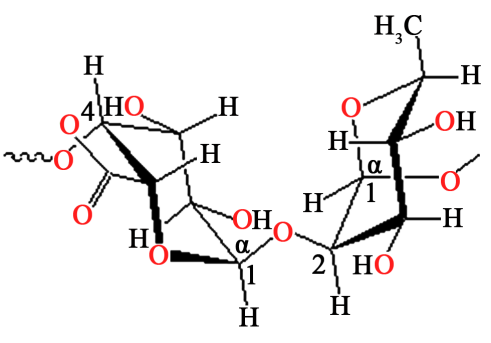

Pectin (P; E-440)

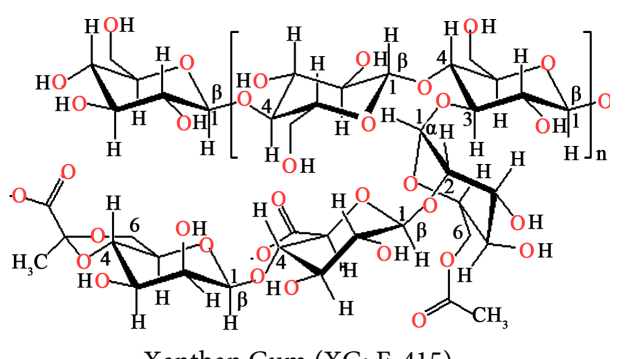

Xanthan Gum (XG; E-415)

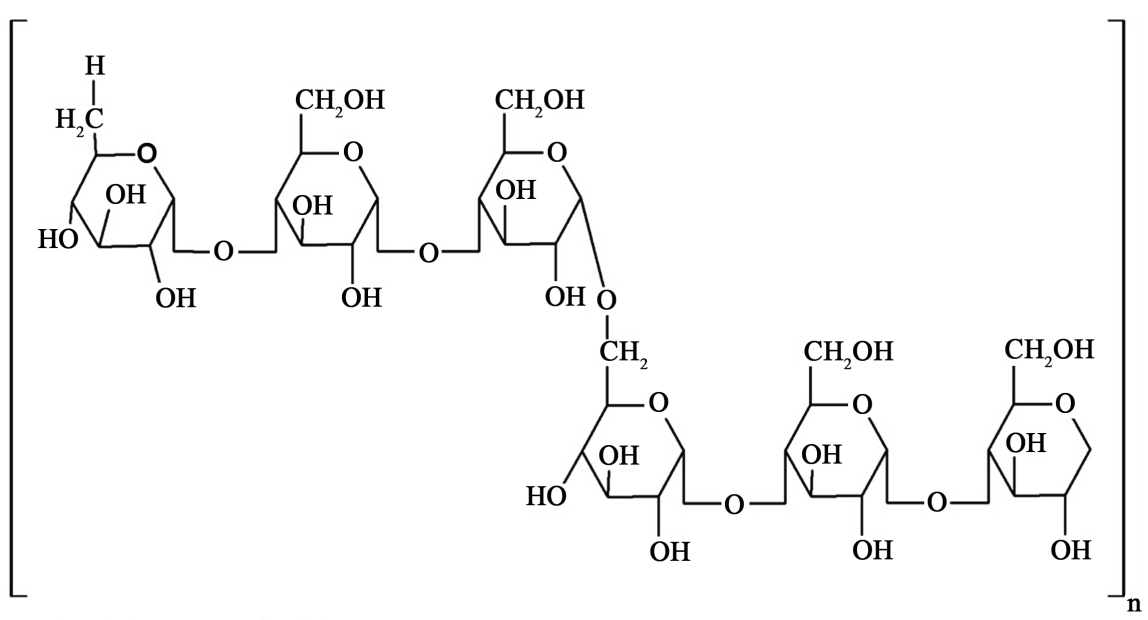

Pullulan (Pu; E1204)

Figure 1. The chemical structure of Arabic gum, k-carrageenan, pectin, xanthan gum, and pullulan hydrocolloids.

\subsection{Breadmaking Procedure}

Baladi bread was prepared according to [18] with some modifications. Briefly, dry ingredients, such as flour (wheat or wheat/soy matrix), $0.5 \%$ dry active yeast, and $1.5 \%$ salt, were mixed at low speed for 1 min using an Orlandi mixer (Model G.P.A. Orlandi mixer, Italy). Water was added (based on Farinograph absorption) at $30^{\circ} \mathrm{C}$, and the resulting mixture was mixed until a consistent dough was formed. After $45 \mathrm{~min}$ of bulk fermentation at $30^{\circ} \mathrm{C}$ and $85 \%$ relative humidity $(\mathrm{RH})$, the dough was divided into small pieces weighing $125 \pm 5 \mathrm{~g}$. The dough pieces were arranged on a wooden board that had been sprinkled with a fine layer of bran and then allowed to rest for $30 \mathrm{~min}$ in the same fermentation cabinet. Dough pieces were flattened by hand up to final diameters ranging from 15 $20 \mathrm{~cm}$. All flattened dough were proofed at $30^{\circ} \mathrm{C}$ and $85 \% \mathrm{RH}$ for $10 \mathrm{~min}$ and then baked at $380^{\circ} \mathrm{C}-400^{\circ} \mathrm{C}$ for $1-2 \mathrm{~min}$. The baked loaves were cooled for 10 $15 \mathrm{~min}$ before being wrapped in plastic bags. All processing stages for making 
baladi bread were performed using a semi-automatic commercial baking line in the official baking house of Toukh city, Qaluobia, Egypt.

\subsection{Chemical Analytical}

Moisture, cured protein, cured fat, and total ash contents of flour or bread were determined according to A.A.C.C. [19]. Total carbohydrates content were calculated by the difference. The energy value of bread was expressed as kcal $100 \mathrm{~g}^{-1}$,

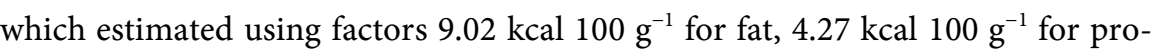

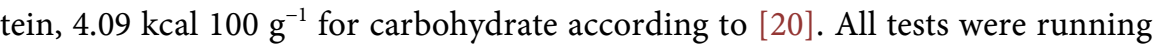
triplicate.

\subsection{Physical Characteristics}

The weight (g) of baked bread was individually determined within 1 hour after baking. The volume $\left(\mathrm{cm}^{3}\right)$ of different bread samples were measured through rape seed displacement method according to A.A.C.C. [19]. The specific volume $\left(\mathrm{cm}^{3} / \mathrm{g}\right)$ was calculated for each of the different bread samples.

\subsection{Dough Properties}

The different properties of dough were evaluated. Dough stability, dough development time, tolerance index, dough softening, and water absorption were determined by Farinograph (Brabender OHG, Duisburg, Germany) according to A.A.C.C. [19]. Extensibility, resistance to extension, and energy of dough were measured using an Extensograph (Brabender, Extensograph, Germany HZ 50). The falling number was determined using a Perten instrument (model 1700, Hagberg, Sweden). Gluten index was determined using a Glutomatic (Perten Instrument AB, Stockholm, Sweden) according to A.A.C.C. [19].

\subsection{Bread Freshness Test}

The freshness rate of bread samples during storage periods 1,3 , and 5 days at room temperature $\left(25^{\circ} \mathrm{C} \pm 2^{\circ} \mathrm{C}\right)$ was determined by Alkaline Water Retention Capacity test (AWRC) according to [21].

\subsection{Crust Color Evaluation}

The crust color of baladi bread samples were determined by measuring $L^{\star}$ (lightness), $a^{*}$ (redness/greenness), and $b^{\star}$ (yellowness/blueness) values, using a Minolta spectrophotometer CM-508d (Minolta Corp., Ramsey, N.J., USA). The instrument was calibrated using a standard white tile $L$-value of 92.46, a value of -0.86 , and $b$ value of -0.16 [22]. Color differences, $\Delta E^{*}$, were calculated using the following equation [23]:

$$
\Delta E^{*}=\left(\Delta L^{* 2}+\Delta a^{* 2}+\Delta b^{* 2}\right)^{1 / 2}
$$

wherein $\Delta L^{\star}, \Delta a^{*}$, and $\Delta b^{\star}$ represent the differences in the color parameters between the sample and the white standard. 


\subsection{Sensory Evaluation of Baladi Bread}

A twelve-member trained panel (students and staff members) from the Food Technology Department, Benha University (aged 19 - 40 years old) evaluated the bread samples. The samples were placed into plates coded by randomly generated three-digit numbers. The sensory evaluation was conducted at 1 hour post-baking the samples. The panelists were asked to evaluate the bread samples based on general appearance (20), separation of layers (20), roundness (15), crumb distribution (15), crust color (10), taste (10), and odor (10) according to previously described procedures [18].

\subsection{Statistical Analysis}

Statistical analysis was carried out by one-way ANOVA, followed by least significance difference test (LSD) for multiple comparisons, using SPSS (version 18 for windows; SPSS Inc., Chicago, IL). $P<0.05$ was considered to indicate statistical significance. Data were treated as a complete randomized design [24]. Results are expressed as mean \pm SD.

\section{Results and Discussion}

\subsection{Composition Analysis of Flour}

Composition analysis of wheat flour (WF), defatted soy flour (DSF), and wheatsoy flour (WSF) matrix are shown in Table 2. Results indicated that the moisture, fat, and carbohydrate contents in DSF were lower than those in WF. Meanwhile, protein and ash contents of DSF were about threefold and fivefold higher than those of WF, respectively. WF and DSF showed a significant difference in protein content $(P \leq 0.05)$. Additionally, WSF $(10 \%)$ showed $2.79 \%$ higher protein content and improved nutritional content compared to WF. The WF and WSF showed a significant difference in gluten content $(P \leq 0.05)$. WF exhibited higher dry gluten and gluten index than WSF. However, the falling numbers of WF and WSF were 285 and 310 Sec., respectively. The findings are consistent with the results of previous studies [25] [26], which reported that DSF bread has around $45 \%$ higher protein content than WF bread and gluten index of $99.36 \%$ for WF bread.

Table 2. Chemical constituents, gluten content, and falling number of wheat flour and/or defatted soy flour.

\begin{tabular}{ccccccccc}
\hline & \multicolumn{7}{c}{ Composition (Mean \pm SD, $\mathbf{n}=3)$} \\
\cline { 2 - 9 } Flour type & Moisture & Protein & Fat & Ash & $\begin{array}{c}\text { Total } \\
\text { carbohydrates }\end{array}$ & $\begin{array}{c}\text { Dry gluten } \\
(\mathrm{g})\end{array}$ & $\begin{array}{c}\text { Gluten index } \\
(\%)\end{array}$ & $\begin{array}{c}\text { Falling number } \\
(\text { Sec })\end{array}$ \\
\hline WF & $11.14^{\mathrm{a}} \pm 0.29$ & $12.56^{\mathrm{c}} \pm 0.37$ & $1.53^{\mathrm{a}} \pm 0.09$ & $1.12^{\mathrm{c}} \pm 0.04$ & $73.65^{\mathrm{a}} \pm 0.95$ & $11.96^{\mathrm{a}} \pm 0.08$ & $99.25^{\mathrm{a}} \pm 0.32$ & $285^{\mathrm{b}} \pm 5.46$ \\
DSF & $9.79^{\mathrm{c}} \pm 0.32$ & $42.77^{\mathrm{a}} \pm 0.87$ & $1.17^{\mathrm{a}} \pm 0.04$ & $6.80^{\mathrm{a}} \pm 0.09$ & $39.47^{\mathrm{b}} \pm 0.82$ & ND & ND & ND \\
WSF & $10.36^{\mathrm{b}} \pm 0.31$ & $15.35^{\mathrm{b}} \pm 0.42$ & $1.51^{\mathrm{a}} \pm 0.14$ & $1.62^{\mathrm{b}} \pm 0.08$ & $71.16^{\mathrm{a}} \pm 0.77$ & $11.45^{\mathrm{b}} \pm 0.11$ & $98.02^{\mathrm{b}} \pm 0.27$ & $310^{\mathrm{a}} \pm 6.11$ \\
\hline
\end{tabular}

${ }_{\text {abc }}$ no significant difference between any two means 'in the same column' have the same superscript letter $(P \geq 0.05)$. WF: wheat flour; DSF: defatted soy flour; WSF: wheat-soy flour. ND: not detected. 


\subsection{Rheological Properties of Dough}

The farinograph parameters of WF or WSF dough containing Pu and/or hydrocolloids are presented in Table 3. The development time, water absorption, stability, and weakening of dough increased with higher amounts of DSF and hydrocolloids. The highest water absorption was recorded in T7 (Pu at $0.4 \%$ ), while the lowest value was obtained in the WF samples. Furthermore, the addition of $\mathrm{Pu}, \mathrm{P}$, and $\mathrm{XG}$ to WSF positively contributed to dough development time and dough stability compared to other hydrocolloids. Meanwhile, AG and KC negatively influenced the mixing tolerance index and dough weakening. The addition of DSF and hydrocolloids improved the extensograph parameters such as extensibility, dough energy, and the resistance to extension of dough, whereas the resistance to extension was increased. The rheological properties of dough are primarily attributed to protein content and the types of additives present in the dough. Higher water absorption capacity, dough development time, and dough stability could be attributed to higher protein content and the ability of hydrocolloids to absorb water within the interrelated network and their interactions with starch granules. Meanwhile, the T7 sample showed the highest water absorption capacity because the $\mathrm{Pu}$ facilitates increased water absorption via hydrogen bonding. These results are agreement with previously reported findings [27]. Moreover, the incorporation of DSF and hydrocolloids led to an increase in resistance to extension and a decrease in extensibility and energy of dough, which may be due to the presence of DSF, which acts by diluting the wheat gluten complex of dough. Inclusion of soy flour at increasing amounts was previously shown to increase the maximum resistance, decrease extensibility, and decrease the area under the curve relative to those of wheat dough [4].

Table 3. Effect of hydrocolloids on rheological properties of dough (Farinograph-Extensograph parameters).

\begin{tabular}{|c|c|c|c|c|c|c|c|c|c|c|}
\hline & \multirow{2}{*}{ Parameters } & \multicolumn{9}{|c|}{ Dough Formula } \\
\hline & & WF & WSF & $\mathrm{T} 1$ & $\mathrm{~T} 2$ & T3 & $\mathrm{T} 4$ & T5 & T6 & T7 \\
\hline \multirow{6}{*}{ 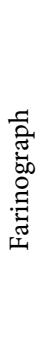 } & Water absorption (\%) & 63 & 65 & 66 & 66 & 66.5 & 67 & 66 & 67 & 68.5 \\
\hline & Arrival time (min) & 1.5 & 2 & 2 & 2 & 1.75 & 2 & 1.75 & 2 & 2 \\
\hline & Dough development time (min) & 2 & 2.5 & 2.5 & 2 & 2 & 2.5 & 2 & 2.5 & 3.5 \\
\hline & Dough stability (min) & 5 & 4 & 4.5 & 5 & 6 & 8 & 7 & 8 & 9.5 \\
\hline & Mixing tolerance index (BU) & 40 & 65 & 70 & 80 & 60 & 50 & 45 & 50 & 50 \\
\hline & Dough weakening (BU) & 90 & 110 & 120 & 130 & 110 & 100 & 95 & 90 & 80 \\
\hline \multirow{3}{*}{ 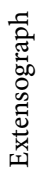 } & Extensibility (mm) & 120 & 110 & 100 & 95 & 100 & 105 & 105 & 110 & 115 \\
\hline & Resistance to extension (BU) & 240 & 280 & 220 & 230 & 260 & 280 & 260 & 280 & 320 \\
\hline & Dough energy $\left(\mathrm{cm}^{2}\right)$ & 90 & 80 & 80 & 70 & 75 & 85 & 80 & 90 & 90 \\
\hline
\end{tabular}

WF: wheat flour and WSF: Wheat-soy flour (WF 90\%: DSF 10\%). 


\subsection{Chemical Constituents and Energy Value of Baladi Bread}

The compositions and energy values of baladi bread incorporated with $\mathrm{Pu}$ or hydrocolloids are presented in Table 4. Results indicated that wheat-soy bread exhibited higher moisture, protein, fat, and ash contents but lower total carbohydrates content relative to wheat bread. On the other hand, wheat bread showed higher energy value relative to those of other samples. Wheat-soy bread with $\mathrm{Pu}$ or hydrocolloids showed significant differences in moisture and protein contents compared to wheat bread alone $(P \leq 0.05)$. The increase in moisture content in bread is due to the presence of hydrocolloids which preserve the moisture. However, the increase in protein content may be attributed to the soy flour. The addition of DSF to WF substantially increased the nutritional value of bread [5] [6].

\subsection{Physical Properties of Baladi Bread}

The physical properties of baladi bread were investigated Table 5. Wheat-soy bread containing $\mathrm{Pu}$ and hydrocolloids showed significant differences in loaf

Table 4. Chemical constituents and energy value of baladi bread with/without hydrocolloids application.

\begin{tabular}{cccccccccc}
\hline \multirow{2}{*}{ Components } & \multicolumn{7}{c}{ Bread formula (Mean \pm SD, $\mathrm{n}=3$ ) } \\
\cline { 2 - 10 } & WF & WSF & T1 & T2 & T3 & T4 & T5 & T6 & T7 \\
\hline Moisture (\%) & $34.26^{\mathrm{c}} \pm 0.53$ & $35.08^{\mathrm{b}} \pm 0.19$ & $35.62^{\mathrm{b}} \pm 0.79$ & $36.04^{\mathrm{a}} \pm 0.49$ & $36.1^{\mathrm{a}} \pm 0.22$ & $36.52^{\mathrm{a}} \pm 0.22$ & $35.78^{\mathrm{b}} \pm 0.36$ & $36.34^{\mathrm{a}} \pm 0.45$ & $37.02^{\mathrm{a}} \pm 0.59$ \\
Protein (\%) & $11.36^{\mathrm{b}} \pm 0.54$ & $13.21^{\mathrm{a}} \pm 0.27$ & $13.36^{\mathrm{a}} \pm 0.27$ & $13.17^{\mathrm{a}} \pm 0.55$ & $13.21^{\mathrm{a}} \pm 0.88$ & $13.34^{\mathrm{a}} \pm 1.13$ & $13.15^{\mathrm{a}} \pm 1.3$ & $13.19^{\mathrm{a}} \pm 0.64$ & $13.26^{\mathrm{a}} \pm 1.41$ \\
Fat (\%) & $1.34^{\mathrm{b}} \pm 0.1$ & $1.59^{\mathrm{a}} \pm 0.09$ & $1.48^{\mathrm{b}} \pm 0.18$ & $1.55^{\mathrm{a}} \pm 0.34$ & $1.54^{\mathrm{a}} \pm 0.28$ & $1.53^{\mathrm{a}} \pm 0.06$ & $1.57^{\mathrm{a}} \pm 0.06$ & $1.59^{\mathrm{a}} \pm 0.11$ & $1.69^{\mathrm{a}} \pm 0.15$ \\
Ash (\%) & $1.19^{\mathrm{b}} \pm 0.09$ & $1.70^{\mathrm{a}} \pm 0.26$ & $1.73^{\mathrm{a}} \pm 0.23$ & $1.75^{\mathrm{a}} \pm 0.09$ & $1.78^{\mathrm{a}} \pm 0.05$ & $1.89^{\mathrm{a}} \pm 0.02$ & $1.68^{\mathrm{a}} \pm 0.12$ & $1.77^{\mathrm{a}} \pm 0.06$ & $1.81^{\mathrm{a}} \pm 0.19$ \\
Total & & & & & & & & & \\
carbohydrates & $52.10^{\mathrm{a}} \pm 0.33$ & $48.42^{\mathrm{b}} \pm 0.25$ & $47.81^{\mathrm{b}} \pm 0.22$ & $47.49^{\mathrm{b}} \pm 0.51$ & $47.37^{\mathrm{b}} \pm 0.68$ & $46.72^{\mathrm{b}} \pm 0.73$ & $47.82^{\mathrm{b}} \pm 1.11$ & $47.11^{\mathrm{b}} \pm 0.54$ & $46.22^{\mathrm{b}} \pm 0.98$
\end{tabular}

(\%)

$\begin{aligned} & \text { Energy value } \\ & \left(\text { Kcal } 100 \mathrm{~g}^{-1}\right)\end{aligned} 274.87^{\mathrm{a}} \pm 6.45266 .51^{\mathrm{b}} \pm 4.89265 .94^{\mathrm{b}} \pm 5.47264 .44^{\mathrm{b}} \pm 3.67264 .03^{\mathrm{b}} \pm 4.23261 .83^{\mathrm{b}} \pm 5.34265 .88^{\mathrm{b}} \pm 3.66263 .34^{\mathrm{b}} \pm 4.82260 .91^{\mathrm{b}} \pm 5.35$

WF: wheat flour and WSF: Wheat-soy flour (WF 90\%: DSF 10\%). abc no significant difference between any two means "in the same row" have the same superscript letter $(P \geq 0.05)$.

Table 5. Physical properties of baladi bread with/without hydrocolloids application.

\begin{tabular}{|c|c|c|c|}
\hline \multirow{2}{*}{ Treatments } & \multicolumn{3}{|c|}{ Properties (Mean $\pm S D, n=3$ ) } \\
\hline & Weight (g) & Volume $\left(\mathrm{cm}^{3}\right)$ & Specific volume $\left(\mathrm{cm}^{3} / \mathrm{g}\right)$ \\
\hline WF & $116.36^{\mathrm{e}} \pm 0.77$ & $291.33^{\mathrm{a}} \pm 1.86$ & $2.5^{\mathrm{a}} \pm 0.03$ \\
\hline WSF & $117.69^{\mathrm{d}} \pm 0.39$ & $282^{\mathrm{d}} \pm 1.53$ & $2.4^{\mathrm{a}} \pm 0.01$ \\
\hline $\mathrm{T} 1$ & $118.91^{\mathrm{cd}} \pm 0.39$ & $283^{c} \pm 2.08$ & $2.38^{\mathrm{ab}} \pm 0.03$ \\
\hline $\mathrm{T} 2$ & $119.96^{\mathrm{bc}} \pm 0.49$ & $284.33^{\mathrm{c}} \pm 2.33$ & $2.37^{\mathrm{b}} \pm 0.02$ \\
\hline $\mathrm{T} 3$ & $120.48^{\mathrm{b}} \pm 0.42$ & $285^{\mathrm{b}} \pm 1.15$ & $2.37^{\mathrm{b}} \pm 0.02$ \\
\hline $\mathrm{T} 4$ & $121.29^{\mathrm{a}} \pm 0.38$ & $286.67^{\mathrm{ab}} \pm 2.03$ & $2.36^{\mathrm{b}} \pm 0.02$ \\
\hline T5 & $119.88^{c} \pm 0.89$ & $284.67^{\mathrm{bc}} \pm 2.33$ & $2.37^{\mathrm{b}} \pm 0.02$ \\
\hline T6 & $120^{\mathrm{b}} \pm 0.51$ & $286.33^{\mathrm{b}} \pm 1.2$ & $2.39^{\mathrm{a}} \pm 0.01$ \\
\hline T7 & $119.41^{\mathrm{c}} \pm 0.24$ & $289.67^{\mathrm{a}} \pm 1.76$ & $2.43^{\mathrm{a}} \pm 0.02$ \\
\hline
\end{tabular}

${ }^{a b c}$ no significant difference between any two means "in the same column" have the same superscript letter $(P \geq 0.05)$. WF: wheat flour; WSF: wheat-soy flour. 
weight, loaf volume, and specific volume compared to the control sample ( $P \leq$ 0.05). The addition of DSF was increased the loaf weight but caused a decrease in the loaf volume. Meanwhile, loaf volume and specific volume were improved upon the addition of $\mathrm{Pu}$ or hydrocolloids, in particular bread samples containing $\mathrm{Pu}, \mathrm{P}$, and $\mathrm{XG}$ which improving the gas-cell stability of gluten. The slight changes in loaf volume may be explained by the dilution of gluten because of the addition of DSF to WF. These results are supported by previous studies [2] [26].

\subsection{Crust Color of Baladi Bread}

The crust color of baladi bread samples were evaluated and shown in Table 6 . Incorporation of DSF modified the crust color of the bread from creamy white to dull brown; in particular, lightness $\left(L^{*}\right)$ and redness $\left(b^{\star}\right)$ values decreased, while browning index $(\mathrm{BI})$ and color difference $(\Delta \mathrm{E})$ values increased. Addition of $\mathrm{Pu}$ or hydrocolloids significantly changed the crust color $(P \leq 0.05)$. In particular, bread samples containing hydrocolloids such as T1 (AG 0.5\% + KC 0.2\%) and $\mathrm{T} 2(\mathrm{AG} 1 \%+\mathrm{KC} 0.4 \%)$ were darker than samples of T3 (P 1\% + XG 0.5\%) and $\mathrm{T} 4$ (P $0.5 \%+\mathrm{XG} 1 \%)$. However, the samples containing Pu exhibited the lightest color. The variability in the crust color of bread may be due to the type of hydrocolloids; both AG and KC produce a dark crust color, while P, XG, and $\mathrm{Pu}$ produce a light crust color. The above results agree with those of a previous report [28].

\subsection{Freshness in Baladi Bread}

Results revealed that measuring the Alkaline Water Retention Capacity (AWRC) is a quick method of determine the staling rate of bread. Higher values of AWRC indicate higher freshness of the bread. The changes in freshness characteristics of baladi bread after 1,3 , and 5 days of storage at room temperature $\left(25^{\circ} \mathrm{C} \pm 2^{\circ} \mathrm{C}\right)$

Table 6. Evaluation of crust color of baladi bread incorporation of hydrocolloids (Hunter color parameters).

\begin{tabular}{ccccccc}
\hline \multirow{2}{*}{ Treatments } & \multicolumn{5}{c}{ Hunter color parameters } \\
\cline { 2 - 7 } & $L^{*}$ & $a^{*}$ & $b^{*}$ & Chroma & Browning index (BI) & $\Delta E^{*}$ \\
\hline WF & 60.14 & 5.43 & 22.47 & 23.12 & 95.62 & 39.86 \\
WSF & 57.58 & 6.74 & 21.78 & 22.80 & 100.64 & 41.82 \\
T1 & 55.82 & 6.23 & 21.94 & 22.81 & 104.10 & 43.29 \\
T2 & 56.33 & 6.15 & 21.85 & 22.70 & 102.29 & 42.80 \\
T3 & 58.46 & 5.89 & 22.05 & 22.82 & 98.08 & 41.08 \\
T4 & 58.78 & 5.87 & 22.19 & 22.95 & 98.05 & 40.89 \\
T5 & 58.85 & 6.03 & 22.07 & 22.88 & 97.71 & 40.79 \\
T6 & 59.65 & 5.55 & 22.29 & 22.97 & 96.02 & 40.18 \\
T7 & 60.54 & 5.24 & 22.51 & 23.11 & 94.60 & 39.53 \\
\hline
\end{tabular}

$L^{\star}, a^{\star}$, and $b^{\star}$ color parameters. WF: wheat flour; and WSF: wheat-soy flour. 
are shown in Figure 2. Wheat bread was fresher than wheat-soy bread under the same conditions, indicating that wheat-soy bread staled faster than wheat bread. However, the wheat-soy bread samples added with Pu, AG, C, P, and XG were fresher than wheat bread alone. The bread sample containing $0.4 \% \mathrm{Pu}$ showed the highest AWRC values after 5 days of storage. The softening of bread was attributed to reduction in gluten-starch interactions in the presence of hydrocolloid molecules. The obtained results confirmed previously reported findings [4] [11].

\subsection{Sensory Evaluation of Baladi Bread}

The sensory evaluation of baladi bread (i.e. general appearance, separation of layers, roundness, crumb distribution, crust color, taste, and odor) were evaluated, as shown in Figure 3 as well, the morphological features in Figure 4. In general, bread samples containing $\mathrm{Pu}$ and/or hydrocolloids received significantly

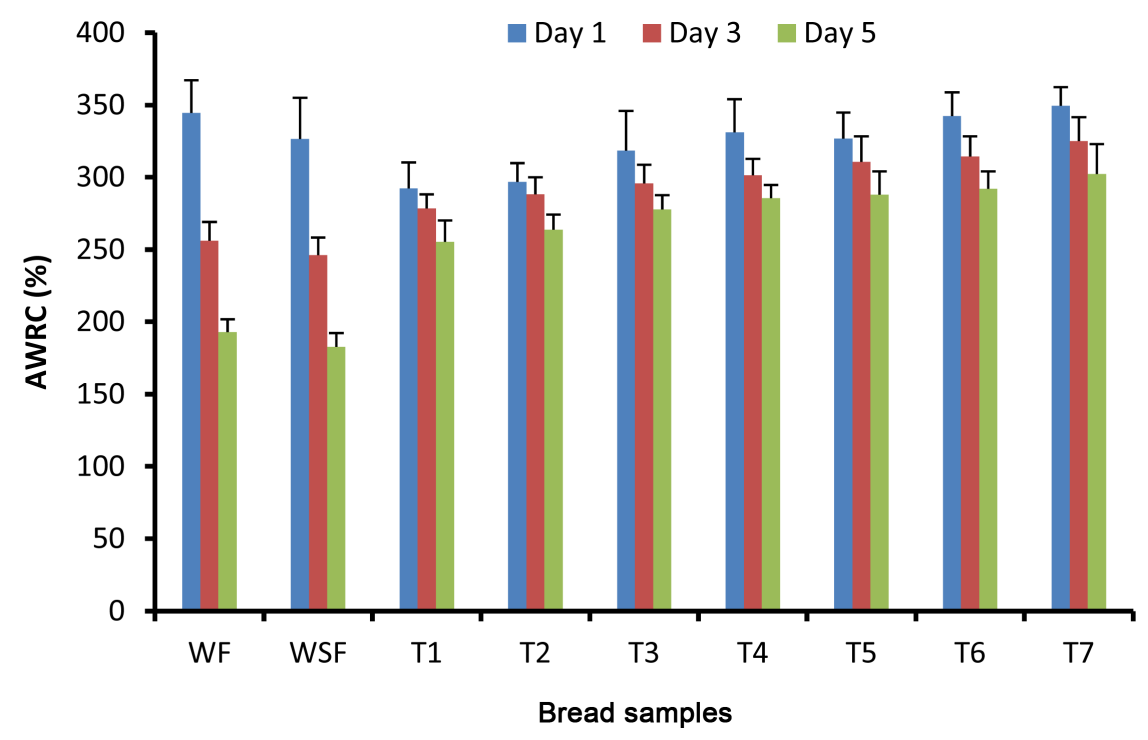

Figure 2. Alkaline Water Retention Capacity (AWRC \%) of baladi bread incorporation of defatted soy flour and/or hydrocolloids at room temperature $\left(25^{\circ} \mathrm{C} \pm 2{ }^{\circ} \mathrm{C}\right)$. Results were expressed as mean $\pm \mathrm{SD}$.

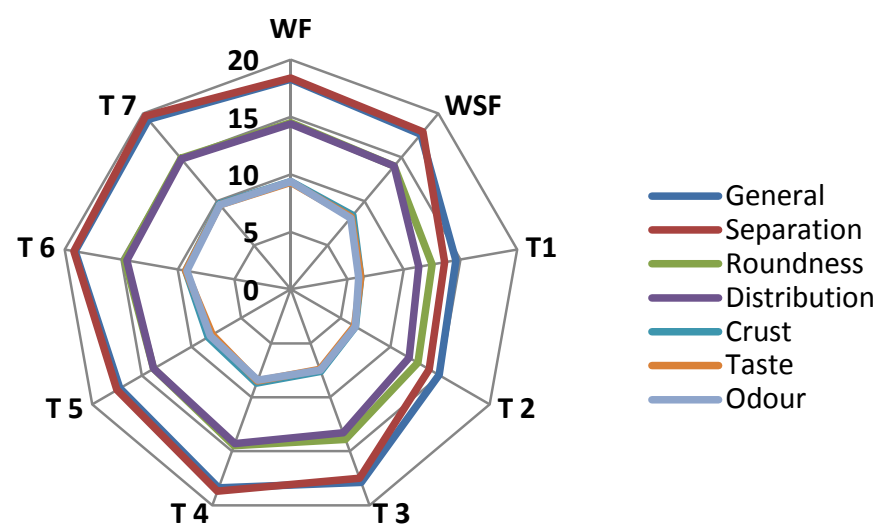

Figure 3. Sensory characterization of baladi bread included hydrocolloids. 


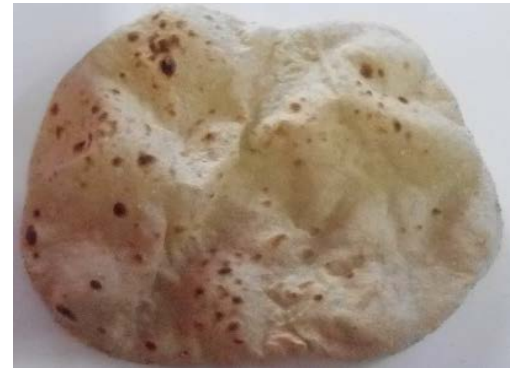

WF-Bread

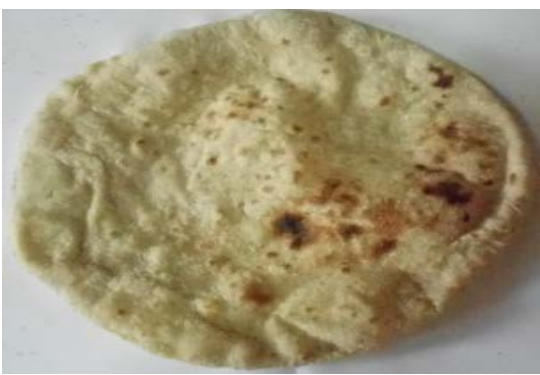

T1-Bread

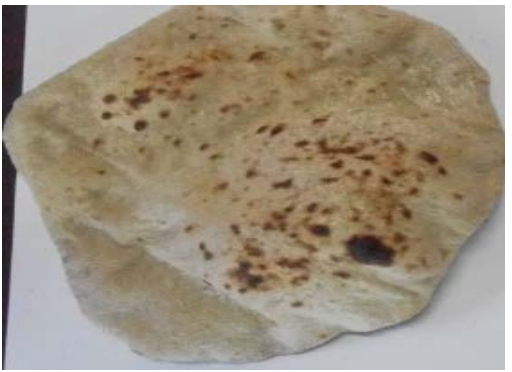

T3-Bread

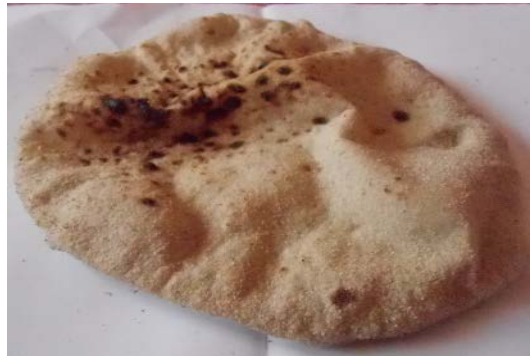

T5-Bread

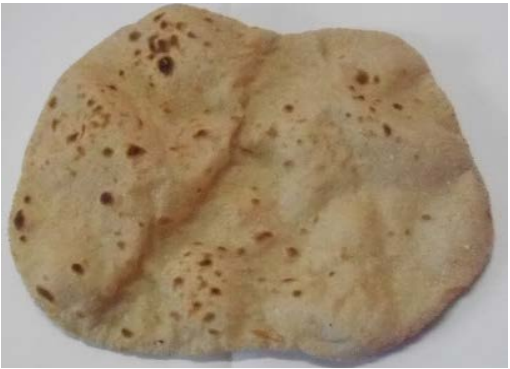

WSF-Bread

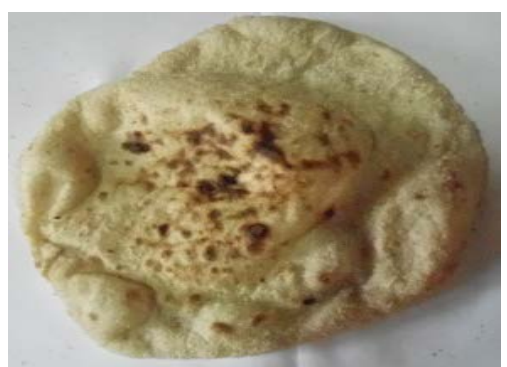

T2-Bread

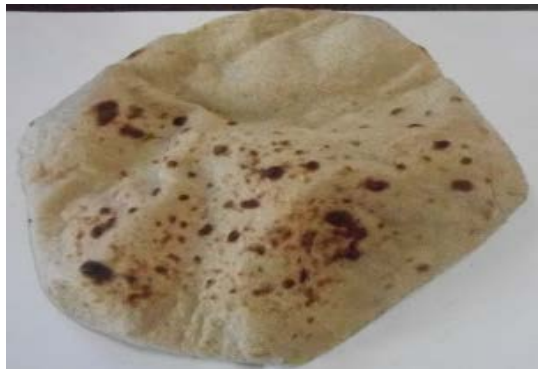

T4-Bread

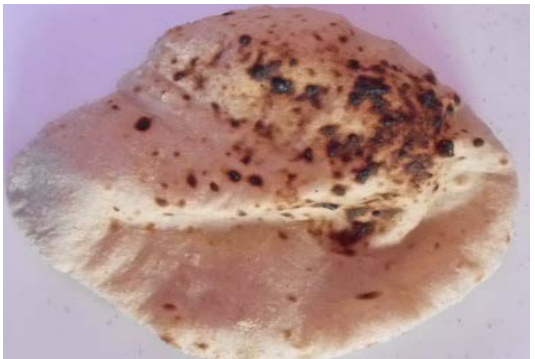

T6-Bread

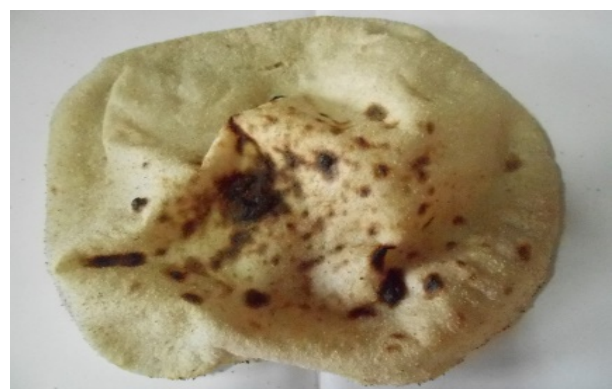

T7-Bread

Figure 4. Morphological features of wheat bread and wheat-soy bread with/without hydrocolloids. 
higher scores compared to the control $(P \leq 0.05)$. The scores corresponding to the general appearance and color of bread samples containing AG and KC (T1 and T2) were lower than those of the control and other treatments. However, the samples containing P or XG or Pu in (T3, T4, T5, T6, and T7) had higher scores. The samples containing $\mathrm{Pu}$ exhibited superior characteristics compared to the other samples containing $\mathrm{P}$ or XG. In general, the T4, T6, and T7 treatments showed the highest scores, particularly the T7 treatment exhibiting the highest acceptability $(P \leq 0.05)$. The hydrocolloids improved the cohesion of starch granules to produce the desired bread structure and texture. As well, the pullulan is novel and a promising material for significantly enhance the sensory acceptability of fresh composite bread. The results are in an agreement with those reported by [29] [30].

From abovementioned results, it was clear that instrumental measurements were harmony with sensory evaluation, which confirms the different hydrocolloids, especially $\mathrm{Pu}$, improved the physical, chemical, rheological, freshness, and sensory attributes of wheat-soy bread.

\section{Conclusion}

The study demonstrated that addition of pullulan $(\mathrm{Pu})$ or hydrocolloid combinations such as AG, KC, P, and XG enhanced dough stability, dough energy, and water absorption capacity of bread dough. These molecules also improved crust color and various sensory properties of the produced baladi bread. P, XG, and $\mathrm{Pu}$ were found to be the best additives that can be used to delay staling because they soften the bread and delay the hardening of bread crumbs. The findings demonstrated the beneficial aspects of $\mathrm{Pu}$ in improving the quality of baladi bread. Therefore, scale-up trials under commercial conditions in Egypt are warranted.

\section{Acknowledgements}

The authors express their sincere gratitude to the Academy of Scientific Research and Technology in Egypt (ASRT) for their financial support. M.K.M would like to thank Alaa Taha for interest in executing the project.

\section{Conflicts of Interest}

The authors declare no conflicts of interest.

\section{References}

[1] CAPMS (2014) Central Administration Public Mobilization and Statistics. Ministry of Agriculture, Egypt.

[2] Yaseen, A.A., Shouk, A. and Ramadan, M.T. (2010) Corn-Wheat Pan Bread Quality as Affected by Hydrocolloids. Journal of American Science, 6, 684-690.

[3] Rosales-Juárez, M., González-Mendoza, B., López-Guel, E.C., Lozano-Bautista, F., Chanona-Pérez, J. and Gutiérrez-López, G. (2008) Changes on Dough Rheological Characteristics and Bread Quality as a Result of the Addition of Germinated and 
Non-Germinated Soybean Flour. Food and Bioprocess Technology, 1, 152-160. https://doi.org/10.1007/s11947-007-0004-3

[4] Ribotta, P.D., Pérez, G.T., Añón, M.C. and León, A.E. (2010) Optimization of Additive Combination for Improved Soy-Wheat Bread Quality. Food and Bioprocess Technology, 3, 395-405. https://doi.org/10.1007/s11947-008-0080-Z

[5] Das, L., Raychaudhuri, U. and Chakraborty, R. (2013) Role of Hydrocolloids in Improving the Physical and Textural Characteristics of Fennel Bread. International Food Research Journal, 20, 2253-2259.

[6] Salve, R. (2011) Effect of Hydrocolloid (Guar Gum) Incorporation on the Quality Characteristics of Bread. Journal of Food Processing \& Technology, 3, 1-7.

[7] Gambuś, H., Sikora, M. and Ziobro, R. (2007) The Effect of Composition of Hydrocolloids on Properties of Gluten-Free Bread. Acta Scientiarum Polonorum: Technologia Alimentaria, 6, 61-74.

[8] Poonnakasem, N., Laohasongkram, K. and Chaiwanichsiri, S. (2015) Influence of Hydrocolloids on Batter Properties and Textural Kinetics of Sponge Cake during Storage. Journal of Food Quality, 38, 441-449. https://doi.org/10.1111/jfq.12167

[9] Gomez, M., Ronda, F., Caballero, P.A., Blanco, C.A. and Rosell, C.M. (2007) Functionality of Different Hydrocolloids on the Quality and Shelf-Life of Yellow Layer Cakes. Food Hydrocolloids, 21, 167-173.

https://doi.org/10.1016/j.foodhyd.2006.03.012

[10] Guarda, A., Rosell, C., Benedito, C. and Galotto, M. (2004) Different Hydrocolloids as Bread Improvers and Antistaling Agents. Food Hydrocolloids, 18, 241-247. https://doi.org/10.1016/S0268-005X(03)00080-8

[11] Shittu, T.A., Aminu, R.A. and Abulude, E.O. (2009) Functional Effects of Xanthan Gum on Composite Cassava-Wheat Dough and Bread. Food Hydrocolloids, 23, 2254-2260. https://doi.org/10.1016/j.foodhyd.2009.05.016

[12] Correa, M.J., Pérez, G.T. and Ferrero, C. (2012) Pectins as Breadmaking Additives: Effect on Dough Rheology and Bread Quality. Food and Bioprocess Technology, 5, 2889-2898. https://doi.org/10.1007/s11947-011-0631-6

[13] Ghanbari, M. and Farmani, J. (2013) Influence of Hydrocolloids on Dough Properties and Quality of Barbari: An Iranian Leavened Flat Bread. Journal of Agricultural Science and Technology, 15, 545-555.

[14] Leathers, T.D. (2003) Biotechnological Production and Applications of Pullulan. Applied Microbiology and Biotechnology, 62, 468-473. https://doi.org/10.1007/s00253-003-1386-4

[15] FDA (2002) US Food and Drug Administration, Center for Food Safety and Applied Nutrition, Office of Food Safety. Agency Response Letter, GRAS Notice: No. GRN 000099.

[16] Torres, J.A. and Velazquez, G. (2005) Commercial Opportunities and Research Challenges in the High Pressure Processing of Foods. Journal of Food Engineering, 67, 95-112. https://doi.org/10.1016/j.jfoodeng.2004.05.066

[17] Shigehisa, T., Ohmori, T., Saito, A., Taji, S. and Hayashi, R. (1991) Effects of High Hydrostatic Pressure on Characteristics of Pork Slurries and Inactivation of Microorganisms Associated with Meat and Meat Products. International Journal of Food Microbiology, 12, 207-215. https://doi.org/10.1016/0168-1605(91)90071-V

[18] Hussein, A., Kamil, M.M., Hegazy, N.A. and El-Nor, S. (2013) Effect of Wheat Flour Supplemented with Barely and/or Corn Flour on Balady Bread Quality. Polish Journal of Food and Nutrition Sciences, 63, 11-18. 
https://doi.org/10.2478/v10222-012-0064-6

[19] AACC (2002) Approved Methods of the American Association of Cereal Chemists. American Association of Cereal Chemists, St. Paul.

[20] Maclean, W., Harnly, J., Chen, J., Chevassus-Agnes, S., Gilani, G. and Livesey, G. (2003) Food Energy-Methods of Analysis and Conversion Factors. Food and Agriculture Organization of the United Nations Technical Workshop Report.

[21] JS, K. and GL, R. (1971) Assessing Quality of Early Generation Wheat Selections with Micro AWRC Test. Cereal Science Today, 16, 313-316, 328.

[22] Ritz, M., Jugiau, F., Rama, F., Courcoux, P., Semenou, M. and Federighi, M. (2000) Inactivation of Listeria monocytogenes by High Hydrostatic Pressure: Effects and Interactions of Treatment Variables Studied by Analysis of Variance. Food Microbiology, 17, 375-382. https://doi.org/10.1006/fmic.2000.0336

[23] Berns, R.S. (2000) Billmeyer and Saltzman's Principles of Color Technology. Wiley, New York.

[24] Steel, R., Torrie, J. and Dickey, D. (1997) Principles and Procedures of Statistics: A Biometrical Approach. 3rd Edition, McGraw-Hill, New York.

[25] Mashayekh, M., Mahmoodi, M.R. and Entezari, M.H. (2008) Effect of Fortification of Defatted Soy Flour on Sensory and Rheological Properties of Wheat Bread. International Journal of Food Science \& Technology, 43, 1693-1698.

https://doi.org/10.1111/j.1365-2621.2008.01755.x

[26] Aleid, S.M., AL-Hulaibi, A., Ghoush, M.A. and Al-Shathri, A. (2015) Enhancing Arabic Bread Quality and Shelf Life Stability using Bread Improvers. Journal of Food Science \&Technology, 52, 4761-4772.

[27] Elhassaneen, Y.A., Elhady, Y.A.A. and Mohamed, N.H. (2014) The Use of Gum Arabic from Acacia Tree (Acacia senegal), a Food Additive to Improve the Nutritional and Rheological Properties of Wheat Flour Dough. Life Science Journal, 11, 385-393.

[28] Eissa, H.A., Hussein, A. and Mostafa, B. (2007) Rheological Properties and Quality Evaluation on Egyptian Balady Bread and Biscuits Supplemented with Flours of Ungerminated and Germinated Legume Seeds or Mushroom. Polish Journal of Food and Nutrition Sciences, 57, 487-496.

[29] Özboy, Ö. (2002) Development of Corn Starch-Gum Bread for Phenylketonuria Patients. Molecular Nutrition \& Food Research, 46, 87-91. https://doi.org/10.1002/1521-3803(20020301)46:2<87::AID-FOOD87>3.0.CO;2-Y

[30] Demirkesen, I., Mert, B., Sumnu, G. and Sahin, S. (2010) Rheological Properties of Gluten-Free Bread Formulations. Journal of Food Engineering, 96, 295-303. https://doi.org/10.1016/j.jfoodeng.2009.08.004 